\title{
O Relatorio do Director da Faculdade
}

\author{
Situação dos professores que na Faculdade de \\ Direito leccionam no Curso do Doutorado on \\ que no Curso de Bacharelado tiveram sua \\ cadeira desdobrada
}

Sobre este assumpto dirigiu o Director da Faculdade ao Ministro da Educação e Conselho Nacional de Educação a consulta que segue, acompanhada da resposta.

PARECER n. 111 - Approvação unanime - 2-9-37.

Processo N.o 369/37, da Secretaria do Conselho Nacional de Educação.

Motivo DA consulta - Situação dos professores que, nas Faculdades de Direito, leccionam disciplinas do Curso de Doutorado.

Commentario - Está assim redigida a consulta apresentada ao Sr. Ministro da Educação e Saude, pelo Director da Faculdade de Direito da Universidade de São Paulo: "Pedimos venia para submetter ás luzes de V. Excia. e, si V. Excia. entender opportuno, á decisão do Conselho Nacional de Educação, as duas questões que passamos a declarar e que reputamos da maior gravidade para o magisterio superior. - Quando se fundou a Universidade de São Pàlo e na Faculdade de Direito, ao lado do Curso de Bacharelado, se creou um Curso de Doutorado, foram nomeados para regel-o alguns cathedraticos da Faculdade; nomeações feitas sem concurso, para simples regencia e em termos que não deixam duvida sobre seu caracter de tem- 
porariedade. Extincto o Curso de Doutorado de accordo com a Lei n. 114 , de 11 de novembro de 1935, pretendem alguns desses professores que eram vitalicios nesse Curso e que, portanto, devem perceber vencimentos na Faculdade como cathedraticos e vitalicios de duas cadeiras. E' a primeira questão. - Um outro professor que era cathedratico por concurso da cadeira de Economia Politica e Sciencia das Finanças no Curso de Bacharelado, foi nomeado para reger a cadeira de Sciencia das Finanças no Curso de Doutorado. Agora retornada essa materia para o Curso de Bacharelado e desdobrada em duas cadeiras - uma de Economia Politica, outra de Sciencia das Finanças - querem entender alguns interessados (não o cathedratico) que o professor não tem de optar por uma das cadeiras e é cathedratico das duas, não só porque fez concurso das duas materias quando unidas numa só cadeira, como tambem porque teria direitos adquiridos á de Sciencia das Finanças por sua nomeação para o Curso de Doutorado. E' a segunda questão. - Temos reagido contra esse modo de ver e demonstrado que improcedem, por todos os motivos, as duas questões. - Juntamos um extracto do nosso ultimo Relatorio ao Governador do Estado, no qual explanamos cumpridamente a materia. Precisando conhecer a palavra das auctoridades superiores do Ensino, não só por motivo de concurso que devemos fazer abrir, como tambem manter o systema sempre seguido na Faculdade de Direito de São Paulo, ousamos solicitar uma solução prompta de V. Excia. e do Conselho Nacional de Educação. Aproveitamos a opportunidade para renovar a V. Excia. a segurança dos nossos sentimentos de respeitosa sympathia e admiração".

$\mathrm{O}$ art. 34 do decreto-lei $\mathrm{n} .^{\circ} 19.852$, de 11 de abril de 1931, reproduzido sob o n. 37 , no Regulamento da então Faculdade de Direito da Universidade do Rio de Janeiro, approvado pelo decreto-lei n. 23.609 , de 20 de dezembro de 1933, está assim redigido: “Art. 34. Os professores do 
curso de doutorado poderão ser designados pela congregação dentre os professores cathedraticos do curso de bacharelado". Evidencia a redacção desse artigo não deverem ser preenchidos com caracter effectivo os cargos de professor do Curso de Doutorado, e, se qualquer duvida pudesse existir a esse respeito, não poderia prevalecer deante da seguinte redacção dada ao art. 31 do primeiro desses decretos-leis, reproduzida no paragrapho unico do art. 3.० do segundo dos referidos decretos: "Art. 31, do Decreto 19.852 - Haverá um professor cathedratico para cada uma das cadeiras do curso de bacharelado". "Paragrapho unico do art. 3..$^{\circ}$ do Decreto 23.609 - Cada uma das cadeiras do curso, de que trata este artigo, será provida por um professor cathedratico" A circumstancia de terem sido nomeados, durante ainda o Governo Provisorio, professores, com caracter effectivo, para a regencia de cadeiras do Curso de Doutorado, não invalida esses dispositivos légaes e muito menos poderia contrariar o que dispõe, em sua primeira parte, o artigo 158 da Constituição de 16 de julho: "Art. 158 - E' vedada a dispensa do concurso, de titulos e provas no provimento dos cargos do magisterio official, bem como, em qualquer curso, a de provas escolares de habilitação, determinadas em lei ou regulamento" O Conselho Nacional de Educação firmou doutrina contraria á possibilidade de accumulo de cadeiras em um mesmo instituto de ensino, ao approvar o parecer n. 190 e respectivo additamento, em 23 de dezembro de 1936, e ao redigir o art. 209 do ante-projecto do Plano Nacional de Educação, nos seguintes termos: “Art. $209-\mathrm{E}$ ' vedado aos professores cathedraticos o exercicio effectivo de duas cadeiras no mesmo estabelecimento, e bem assim o das funç̧ões de secretario ou de qualquer outro cargo administrativo de hierarchia inferior". 0 accumulo de cadeiras em um mesmo instituto traria, além disso, sérias difficuldades para o pronunciamento das congregações, nos casos em que a deliberação houvesse de ser tomada por maioria absoluta ou por $2 / 3$ da totalidade dos seus mem- 
bros, equivalente, nos termos da lei, á das cadeiras leccionadas.

Conclusão - Parece á Commissão merecer as seguintes respostas a consulta formulada pelo Sr. Director da Faculdade de Direito da Universidade de São Paulo: 1. ${ }^{\mathrm{a}}$ Sómente poderão considerar-se vitalicios nos cargos que exerciam no Curso de Doutorado os professores que, ou foram nomeados, com esse caracter, por decreto-lei, durante o Governo discricionario, ou por concurso, durante esse periodo ou depois de promulgada a Constituição de 16 de julho. $2^{\mathrm{a}}$ - Ao professor, a que fôra confiada, no Curso de Doutorado, a regencia de uma cadeira ulteriormente transferida para o de Bacharelado, e então desdobrada, cabe o direito de optar por uma dellas, mas não o de accumular effectivamente as duas cadeiras em que foi desdobrada aquella para que fizéra concurso. - SS. 31 de Agosto de 1937 (aa) Raul Leitão da Cunha, relator - Leonel Franca, S. J. Visto: (a) Americo Lacombe. Homologo o parecer. 8-IX-37 - (a) Capanema. 